https://www.journal-imab-bg.org

Original article
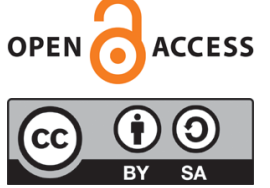

\title{
COMPARATIVE STUDY OF ANTIBACTERIAL ACTIVITY OF PHOTOACTIVATED DISINFECTION WITH FOTOSAN AND STANDARD ENDODONTIC TREATMENT
}

\author{
Tzvetelina G. Gueorgieva ${ }^{1}$, Raina T. Gergova ${ }^{2}$ \\ 1) Department of Conservative Dentistry, Faculty of Dental Medicine, Medical \\ University Sofia, Bulgaria. \\ 2) Department of Medical Microbiology, Faculty of Medicine, Medical \\ University Sofia, Bulgaria.
}

\begin{abstract}
Introduction: The purpose of endodontic treatment is to eliminate the bacterial infection in the root canal system and allow healing of apical periodontitis. Sometimes the anatomical complexity of the root canal system makes complete removal of bacteria almost impossible even if the conventional methods of chemo-mechanical debridement are performed strictly according to the protocol. So additional methods of root canal disinfection can be applied such as photoactivated disinfection (PAD).

Purpose: The aim of our study was to compare the antibacterial activity of PAD with FotoSan, and conventional endodontic therapy in the treatment of infected root canals.

Materials and methods: The study involved 36 teeth of patients who are diagnosed with pulp necrosis or with the periapical chronic periodontitis and require endodontic treatment and divided into two groups of 18 teeth each. The first microbiological sample was taken by placing a sterile paper point in the root canal, after endodontic access cavity preparation.

All root canals are prepared by Protaper Universal rotary instruments (Maillefer Instruments SA, Ballaigues, Switzerland). In the first group, the disinfection of the root canals was made with photoactivated disinfection with FotoSan. In the second group was performed the endodontic treatment with the standard protocol of irrigation $-2.5 \%$ sodium hypochlorite solution and $17 \%$ EDTA. After that, the root canals are dried with sterile points, and a second microbiological sample is taken.

Results: In all compared pairs, there was no significantly different effect regarding the number of microorganisms.

Conclusions; The disinfection with $\mathrm{NaOCl}$ has the strongest antimicrobial effect in this study. Second place is occupied by PAD with FotoSan. We believe that the established antimicrobial effect of PAD make the method appropriate as complementary to routine endodontic treatment.
\end{abstract}

Keywords: Endodontic treatment, root canal disinfection, photoactivated disinfection,

\section{INTRODUCTION}

The purpose of endodontic treatment is to eliminate the bacterial infection in the root canal system and allow healing of apical periodontitis. Primary root canal therapy is a highly predictable procedure; however, the inability to sufficiently disinfect the root canal system may lead to failure or persistent apical pathosis [1]. While mechanical debridement combined with chemical irrigation removes the bulk of infecting microorganisms, residual bacteria are readily detectable in approximately one-half of teeth just prior to obturation [2]. Certain operative problems such as inadequate instrumentation, a missed canal, or an inadequate restoration may lead to complications after the endodontic treatment. [3]. In addition, the anatomical complexity of the root canal system makes complete debridement of bacteria almost impossible even if conventional methods of chemo-mechanical debridement are performed strictly according to the protocol [3, 4, 5].

Photodynamic therapy (PDT) is a technique that utilizes reactive oxygen species (ROS) produced by a nontoxic dye or photosensitizer (PS) molecule in the presence of low intensity visible light to kill mammalian or microbial cells. The photochemical process involves exciting the PS molecule with visible light of the appropriate wavelength matched to an absorption band. The PS molecule goes to the first excited singlet state which may then undergo intersystem crossing to slightly lower energy but longer-lived triplet state. The long-lived triplet state further reacts via type I or/and type II photochemical pathways to produce superoxide, hydroxyl radicals $[6,7]$, and singlet oxygen [8] respectively, leading to cytotoxicity.

Though PDT was discovered in the field of microbiology over 100 years ago, it has been mostly applied for cancer treatment and ophthalmology. Its application in the field of infectious diseases underwent a major setback with the discovery of antibiotics in the 1940s. But with the recent rise in antibiotic resistance throughout the world, there has been renewed interest in alternative antimicrobial therapies. Antimicrobial PDT also known as photoactivated disinfection (PAD) represents an alterna- 
tive treatment for drug resistant pathogens and has made a comeback as a possible approach to treat multidrug resistant infections. [9, 10, 11].

The aim of our study was to compare the antibacterial activity of PAD with FotoSan, and conventional endodontic therapy in the treatment of infected root canals.

\section{MATERIALS AND METHODS}

The study involved 36 teeth of patients who are diagnosed with pulp necrosis or with chronic periapical periodontitis and require endodontic treatment.

\section{Case selection}

Patients complete medical history was taken. Those who have systemic diseases or have taken antibiotics for the last three months are excluded from the study. Each patient signs an informed consent. In each case (tooth), a preliminary X-ray is taken to detect the presence of periapical changes and get an idea of the morphology, length and number of root canals.

The teeth are isolated with a rubber dam. Then they are cleaned with $2 \%$ chlorhexidine solution. Sterile burs are used for the preparation of the endodontic cavity and access. Old obturations and carious lesions are carefully removed. Microbiological samples are taken by placing a sterile paper point in the root canal for 60 seconds. After removing the paper point from the root, it is immediately placed in a sterile transport environment and then transported to a microbiological laboratory. This is the initial microbiological sample.

The treated teeth are divided into two groups depending on the method used for root canal disinfection:

I group - 18 cases - root canals are prepared by
Protaper Universal rotary instruments (Maillefer Instruments SA, Ballaigues, Switzerland). Root canal irrigation is performed with sterile saline solution, after working with each instrument.

Once the root canals have been prepared, they are dried with sterile paper points. In this group, the disinfection is made with photoactivated disinfection with FotoSan. A diode laser with a wavelength that matches the absorption spectrum of the photosensitizer FotoSan is used. A photosensitizer - $0.5 \mathrm{ml}$ is introduced into the root canals.For radiation, a "Lacsta-Milon" laser with a wavelength of $665 \mathrm{~nm}, 1$ minute with the following parameters: $\mathrm{F}=0$ (continuous emission), $\mathrm{PR}=4, \mathrm{E}=999, \mathrm{P}$ $=200$, power of $200 \mathrm{~mW} / \mathrm{cm}^{2}$ to activate the photodynamic process. Irradiation is performed with circular movements in the apical-coronary direction for 1 minute with a fiber-optic fiber with a thickness of $200 \mu \mathrm{m}$ at $1 \mathrm{~mm}$ from the working length. Root canals are irrigated with saline to remove the photosensitizer, dried with sterile paper points, and a microbiological sample is taken.

II group - 18 cases - root canals are prepared by Protaper Universal rotary instruments (Maillefer Instruments SA, Ballaigues, Switzerland). After working with each canal instrument, the root canals are irrigated with $2.5 \%$ sodium hypochlorite solution and $17 \%$ EDTA. Root canals are dried with sterile paper points, and a second microbiological sample is taken.

\section{RESULTS}

In all compared pairs, there was no significantly different effect regarding the number of microorganisms (MO) (Table 1, 2, 3, 4).

Table 1. Antibacterial activity of PAD with FotoSan in infected root canals

\begin{tabular}{|c|l|l|l|l|}
\hline $\begin{array}{c}\text { Sample } \\
\text { number }\end{array}$ & $\begin{array}{l}\text { Isolated microorganisms } \\
\text { prior to treatment }\end{array}$ & $\begin{array}{l}\text { Amount of micro- } \\
\text { organisms /cfu/ml }\end{array}$ & $\begin{array}{l}\text { Isolated microorganisms } \\
\text { after disinfection with PAD }\end{array}$ & $\begin{array}{l}\text { Amount of microor- } \\
\text { ganisms /cfu/ml }\end{array}$ \\
\hline 1 & Streptococcus gordonii & 5.100000 & No & No \\
& Neisseria polysacharea & 2.10000 & No & No \\
\hline 2 & Enterococcus .faecalis & 8.100000 & No & No \\
& Bacillus brevis & 6.100000 & No & 4.1000 \\
\hline 3 & Streptococcus pyogenes & 3.100000 & K. pneumoniae & No \\
\hline 4 & Klebsiella pneumoniae & 7.1000000 & Str.mutans & 2.1000 \\
\hline 5 & Streptococcus mutans & 3.100000 & No & 3.1000 \\
& Actinomyces.viscosus & 6.10000 & E.faecalis & No \\
\hline 6 & E. faecalis & 2.10000000 & & 3.1000 \\
& Lactobacillus. acidophillus & 5.10000 & No & No \\
\hline 7 & Staphylococcus aureus & 8.10000 & No & No \\
\hline 8 & Streptococcus mitis & 2.100000 & No & No \\
\hline 9 & E.faecalis & 4.100000 & No & No \\
& S.aureus & 1.100000 & No & \\
\hline
\end{tabular}




\begin{tabular}{|l|l|l|l|l|}
\hline 10 & Streptococcus sanguis & 3.100000 & No & No \\
& Moraxella. catarrhalis & 2.100000 & No & No \\
\hline 11 & E. faecalis & 3.100000 & No & No \\
\hline 12 & Stapylococcus.haemolyticus & 8.1000000 & Staph.haemolyticus & 3.100 \\
& E. faecalis & 4.10000 & & \\
\hline 13 & S.mutans & 2.100000 & No & No \\
& Cor. xerosis & 5.10000 & No & No \\
\hline 14 & S. aureus & 4.100000 & No & No \\
& Enterobacter. cloaceae & 5.1000000 & Ent. cloaceae & 2.10000 \\
\hline 15 & Streptococcus intermedius & 2.10000 & No & No \\
& Actinomyces neuii & 9.10000 & No & No \\
\hline 16 & S.mutans & 3.100000 & No & No \\
& S. mitis & 1.100000 & No & No No \\
\hline 17 & E.faecalis & 1.100000 & No & No \\
\hline 18 & E.faecalis & 8.10000 & No & No \\
& Enterobacter. aerogenes & 9.100000 & E. aerogenes & 3.1000 \\
\hline
\end{tabular}

Table 2. Antibacterial activity of 2,5\% $\mathrm{NaOCl}$ and $17 \%$ EDTA in infected root canals

\begin{tabular}{|c|c|c|c|c|}
\hline $\begin{array}{l}\text { Sample } \\
\text { number }\end{array}$ & $\begin{array}{l}\text { Isolated microorganisms } \\
\text { prior to treatment }\end{array}$ & $\begin{array}{l}\text { Amount of micro- } \\
\text { organisms /cfu/ml }\end{array}$ & $\begin{array}{l}\text { Isolated microorganisms } \\
\text { after disinfection with } 2,5 \% \\
\mathrm{NaOCl} \text { and } 17 \% \text { EDTA }\end{array}$ & $\begin{array}{l}\text { Amount of micro- } \\
\text { organisms } / \mathrm{cfu} / \mathrm{ml}\end{array}$ \\
\hline 1 & $\begin{array}{l}\text { E.faecalis } \\
\text { A.viscosus }\end{array}$ & $\begin{array}{l}5 \times 100000 \\
3 \times 10000\end{array}$ & $\begin{array}{l}\text { No } \\
\text { No }\end{array}$ & $\begin{array}{l}\text { No } \\
\text { No }\end{array}$ \\
\hline 2 & $\begin{array}{l}\text { Streptococcus parasanguis } \\
\text { Kingella denitrificans }\end{array}$ & $\begin{array}{l}4 \times 100000 \\
7 \times 10000\end{array}$ & $\begin{array}{l}\text { No } \\
\text { No }\end{array}$ & $\begin{array}{l}\text { No } \\
\text { No }\end{array}$ \\
\hline 3 & Klebsiella.pneumoniae & $9 \times 100000$ & K.pneumoniae & $1 \times 100$ \\
\hline 4 & Candidaalbicans & $3 \times 10000$ & No & No \\
\hline 5 & S.mitis & $2 \times 10000$ & No & No \\
\hline 6 & $\begin{array}{l}\text { E.faecalis } \\
\text { E. cloaceae }\end{array}$ & $\begin{array}{l}3 \times 100000 \\
2 \times 10000\end{array}$ & $\begin{array}{l}\text { No } \\
\text { No }\end{array}$ & $\begin{array}{l}\text { No } \\
\text { No }\end{array}$ \\
\hline 7 & $\begin{array}{l}\text { Arcanobacterium haemolyticum } \\
\text { E. faecalis } \\
\text { Bacillus brevis }\end{array}$ & $\begin{array}{l}8 \times 100000 \\
5 \times 10000 \\
6 \times 10000\end{array}$ & $\begin{array}{l}\text { No } \\
\text { No } \\
\text { No }\end{array}$ & $\begin{array}{l}\text { No } \\
\text { No } \\
\text { No }\end{array}$ \\
\hline 8 & $\begin{array}{l}\text { S.sanguis } \\
\text { Corynebacteriumulcerans }\end{array}$ & $\begin{array}{l}4 \times 1000000 \\
1 \times 10000\end{array}$ & $\begin{array}{l}\text { Str.sanguis } \\
\text { No }\end{array}$ & $\begin{array}{l}2 \times 1000 \\
\text { No }\end{array}$ \\
\hline 9 & $\begin{array}{l}\text { E. faecalis } \\
\text { Eikenella.corrodens }\end{array}$ & $\begin{array}{l}8 \times 100000 \\
9 \times 100000 \\
\end{array}$ & $\begin{array}{l}\text { No } \\
\text { No }\end{array}$ & $\begin{array}{l}\text { No } \\
\text { No }\end{array}$ \\
\hline 10 & $\begin{array}{l}\text { Str.pyogenes } \\
\text { Lactobacillus fermentum }\end{array}$ & $\begin{array}{l}6 \times 100000 \\
6 \times 10000\end{array}$ & $\begin{array}{l}\text { No } \\
\text { No }\end{array}$ & $\begin{array}{l}\text { No } \\
\text { No }\end{array}$ \\
\hline 11 & $\begin{array}{l}\text { S.gordonnii } \\
\text { Kingella kingae } \\
\text { Neisseria polysaccharea }\end{array}$ & $\begin{array}{l}6 \times 100000 \\
5 \times 100000 \\
2 \times 10000\end{array}$ & $\begin{array}{l}\text { No } \\
\text { No } \\
\text { No No No }\end{array}$ & $\begin{array}{l}\text { No } \\
\text { No } \\
\text { No }\end{array}$ \\
\hline 12 & $\begin{array}{l}\text { S.aureus } \\
\text { E. faecalis } \\
\text { Streptococcus.constelatus }\end{array}$ & $\begin{array}{l}6 \times 10000 \\
8 \times 10000 \\
3 \times 100000\end{array}$ & $\begin{array}{l}\text { No } \\
\text { No } \\
\text { No Str.constelatus }\end{array}$ & $\begin{array}{l}\text { No } \\
\text { No } \\
9 \times 100\end{array}$ \\
\hline
\end{tabular}




\begin{tabular}{|l|l|l|l|l|}
\hline 13 & Gemella morbillorum & $8 \times 100000$ & No & No \\
& S.aureus & $2 \times 10000$ & No & No \\
\hline 14 & E.faecalis & $7 \times 100000$ & No & No \\
& C.matruchotii & $5 \times 10000$ & No & No \\
\hline \multirow{2}{*}{15} & E.faecalis & $6 \times 10000$ & No & No \\
& Actinomyces neuii & $7 \times 100000$ & No & $3 \times 10$ \\
\hline \multirow{2}{*}{16} & Morganella morganii & $8 \times 100000$ & M.morganii & No \\
& Staph.aureus & $9 \times 10000$ & No & No \\
\hline 17 & E.faecalis & $4 \times 1000000$ & No & No \\
& Streptococcus.anginosus & $6 \times 10000$ & No & No \\
& Neisseria mucosa & $5 \times 10000$ & No & No \\
\hline \multirow{2}{*}{18} & E.coli & $2 \times 100000$ & No & No \\
& Candida albicans & $3 \times 1000$ & & \\
\hline
\end{tabular}

Table 3. Numbers of microorganisms before and after treatment

\begin{tabular}{|l|l|l|l|l|l|l|l|}
\hline \multirow{2}{*}{ Method } & \multirow{2}{*}{$\begin{array}{l}\text { Before and after } \\
\text { treatment }\end{array}$} & \multirow{2}{*}{$\mathbf{N}$} & \multicolumn{4}{|c|}{ Amount of microorganisms /cfu/ml } & \multirow{2}{*}{$\mathbf{p}$} \\
\cline { 5 - 8 } & & & Mean & Median & Min & Max & \\
\hline \multirow{2}{*}{ NaOCl/EDTA } & Before treatment & 18 & 1035722,2 & 755000,0 & 20000,0 & 4110000,0 & $<0.001$ \\
\cline { 2 - 7 } & After treatment & 18 & 168,3 & 0,0 & 0,0 & 2000,0 & \\
\hline \multirow{2}{*}{ FAD FotoSan } & Before treatment & 18 & 2571666,6 & 400000,0 & 100000,0 & 20050000,0 & $<0.001$ \\
\cline { 2 - 7 } & After treatment & 18 & 2238,8 & 0,0 & 0,0 & 2000,0 & \\
\hline
\end{tabular}

In all two methods, significant differences in the amounts of microorganisms before and after treatment $(\mathrm{p}<0.001)$ have been observed (Table 4).

Table 4. Numbers of microorganisms before and after treatment

\begin{tabular}{|c|c|c|c|c|c|c|c|}
\hline \multirow{2}{*}{$\begin{array}{l}\text { Before and } \\
\text { after treatment }\end{array}$} & \multirow{2}{*}{ Method } & \multirow{2}{*}{$\begin{array}{l}\text { Number } \\
\text { of samples }\end{array}$} & \multicolumn{4}{|c|}{ Amount of microorganisms } & \multirow{2}{*}{$\mathbf{p}$} \\
\hline & & & Mean & Median & Min & Max & \\
\hline \multirow{2}{*}{ Before treatment } & $\mathrm{NaOCl} / \mathrm{EDTA}$ & 18 & 1035722,2 & 755000,0 & 20000,0 & 4110000,0 & \multirow{2}{*}{0,569} \\
\hline & PAD Fotosan & 18 & 2571666,6 & 400000,0 & 100000,0 & 20050000,0 & \\
\hline \multirow{2}{*}{ After treatment } & $\mathrm{NaOCl} / \mathrm{EDTA}$ & 18 & 168,3 & 0,0 & 0,0 & 2000,0 & \multirow{2}{*}{0,130} \\
\hline & PAD Fotosan & 18 & 2238,8 & 0,0 & 0,0 & 2000,0 & \\
\hline
\end{tabular}

$\mathrm{NaOCl}$ has the most strong antimicrobial activity in vivo. The remaining causative agents, after the irrigation and disinfection of root canals, are in a small amount - only $10 \%$.

After in vivo PAD with FotoSan, approximately $23 \%$ of the isolates remained with $3 \mathrm{lg}$ less than the initial isolation in smaller amount $1000-10,000 \mathrm{cfu} / \mathrm{ml}$ again at the expense of the enterobacteriaceae from the group KES, Enterobacter spp., Klebsiella spp.

\section{DISCUSSION}

From the two tested patient groups with 18 samples in each group, predominantly polymicrobial associations and rarely monoinfection with a predominance of Gram-positive species were isolated.
It is noteworthy that the most strong antimicrobial activity in vivo has $\mathrm{NaOCl}$ (only $10 \%$ of the initially isolated microorganisms remain after the action of this disinfection method - the effect is 90\%) and PAD with FotoSan (only $23 \%$ of the initially isolated microorganisms remain after the impact of this disinfection method, i.e. the effect is 77\%). Microorganisms (MO) remaining after treatment are Gram-positive cocci - oral streptococci that are likely to reinfect the dental canals despite the successful removal of the other causative agents from the original association which they were isolated from. Other MO that remain after treatment are enterobacteriaceae of the KES group, Enterobacter spp., Klebsiella spp. These species form extremely rigid biofilms due to the overproduction of substances in capsule form and many other ad- 
hesion molecules on the surface of their cell wall as outer membrane proteins, lipopolysaccharides and adhesive piles. They are also polyresistant to many antimicrobial agents and are the cause of problematic in-hospital infections. Our results coincide with data from other studies showing a very good antibacterial effect of PAD [4, 12]. Some authors' panels - Fonseca et al. (2008) [5] reported a $99.9 \%$ reduction in MO after PAD application. The difference in the results obtained by us, and these researchers may be due to differences in the characteristics of light sources, concentration and amount of photosensitizers, etc.[4].

The results of this clinical study show a very good antibacterial effect of PAD with FotoSan. This is a prerequisite for the usage of the method as additional in endodontic treatment for root canal (RC) disinfection, especially in cases where it is necessary to work with lower concentrations of the rinsing solutions.

The conducted clinical study allows for the reduction of MO in RC after treatment applying the two methods. The used microbiological method permits discovering the MO only in RC lumen, i.e. those MOs, which adhere to the paper point while taking the second microbiological sample. It does not give an idea of the MOs that have stuck to the canal walls and that have entered the dentinal tubules and micro-canals of the apical delta. They are the cause of root canal system re-infection after filling the canal and the appearance of periodontitis after the treatment of infected $\mathrm{RC}$ or the failure to treat existing periodontitis. However, the microbiological method used makes it possible to make a comparative assessment of the effectiveness of the two methods. The weaker effect of PAD compared to the conventional method of rinsing solutions in our study was obtained using the specific conditions of the experiment with the particular the photosensitizers FotoSan (concentration, amount, irradiation time, duration of exposure, type of MO, standardized conditions for taking the microbiological sample). But FotoSan is just one of the many photosensitizers and prob- ably not the best. Preclinical studies with Zn-phthalocyanine showed that it has a better effect compared to FotoSan [12]. New future clinical studies after the certification of Zn-phthalocyanine will show their effectiveness as photosensitizers in PAD in root canal treatment.

\section{CONCLUSION}

The disinfection of root canals with $\mathrm{NaOCl}$ has the strongest antimicrobial effect in clinical studies $(90 \%$ against all microbial isolates). Second place is occupied by PAD with FotoSan (with slightly lower antimicrobial effect against polyresistant klebsiella and enterobacter) having $77 \%$ antibacterial effect against all microbial isolates.

In the clinical application of the two methods, we found that there was no evidence of staining soft and hard tooth tissues for hypersensitivity or toxicity reactions. We believe that the lack of an irritant effect of light or and the established antimicrobial effect of PAD make the method appropriate both as complementary to routine ones and as methods of choice in situations severely impeding the conventional method of rinsing with antiseptic solutions.

The microbiological studies were conducted at Bulgarian Academy of Sciences, Microbiology Institute "Stefan Angelov" (associated with the Institute "Pasteur" in Paris and the Department of Microbiology at the Medical Faculty of Medical University - Sofia). They were carried out by Assoc. Prof. R. Gergova (Department of Medical Microbiology, Medical Faculty, Medical University of Sofia).

For quantitative evaluation of microbial isolates was used the quantitative method of strikes for inoculation [IMAB 2013]. The biochemical identification of endodontic pathogens was conducted using the identification systems suach as Crystal GP, Crystal NH and Crystal Ana BD (Becton Dickinson, Germany)

\section{REFERENCES:}

1. Gergova R, Georgieva T, Angelov I, Mantareva V, Valkanov S, Mitov I, et al. Photodynamic therapy with water-soluble phtalocyanines against bacterial biofilms in teeth root canals. SPIE. Digital Library. 2012; 8427: Biophotonics: Photonic Solutions for Better Health Care III, 842744. [Crossref]

2. Giuliani F, Martinelli M, Cocchi A, Arbia D, Fantetti L, Roncucci G. In vitro resistance selection studies of RLP068/Cl, a new Zn(II) phthalocyanine suitable for antimicrobial photodynamic therapy. Antimicrob Agents Chemother. 2010 Feb;54(2):

\section{7-42. [PubMed]}

3. Chivatxaranukul P, Dashper SG, Messer HH. Dentinal tubule invasion and adherence by Enterococcus faecalis. Int Endod J. 2008 Oct; 41(10): 873-882. [PubMed].

4. Dogandzhiyska V, Gergova R, Dimitrov S, Doychinova M. Antimicrobial activity of Photodynamic therapy against microorganisms isolated from deep carious lesions. $J$ of IMAB. 2013 Jul-Dec;19(4):430-434. [Crossref]

5. Fonseca MB, Tessare PO Jr, Pallota RC, Filho HF, Denardin OV, Rapoport A, et al. Photodynamic therapy for root canals infected with Enterococcus faecalis. Photomed Laser Surg. 2008 Jun;26(3):209-13. [PubMed]

6. Solana C, Ruiz-Linares M, Baca P, Valderrama MJ, Arias-Moliz MT, Ferrer-Luque CM. Antibiofilm Activity of Sodium Hypochlorite and Alkaline Tetrasodium EDTA Solutions. $J$ Endod. 2017 Dec;43(12):2093-2096. [PubMed]

7. Gergova RT, Gueorgieva T, Dencheva-Garova MS, KrastevaPanova AZ, Kalchinov V, Mitov I, et al. Antimicrobial activity of different disinfection methods against biofilms 
in root canals. J Investig Clin Dent. 2016 Aug;7(3):254-62. [PubMed]

8. Signoretti FG, Endo MS, Gomes BP, Montagner F, Tosello FB, Jacinto RC. Persistent Extraradicular Infection in Root-filled Asymptomatic $\mathrm{Hu}-$ man Tooth: Scanning Electron Microscopic Analysis and Microbial Investigation after Apical Microsurgery. $J$ Endod. 2011 Dec;37(12):1696-700. [PubMed]

9. Kuzekanani M, Plotino G, Gutmann JL. Current Applications of Lasers in Endodontics. G Ital Endod.
2019 Mar;33(02):13-23. [Crossref]

10. Matos Neto M, Santos SS, Leão MV, Habitante SM, Rodrigues JR, Jorge AO. Effectiveness of three instrumentation systems to remove Enterococcus faecalis from root canals. Int Endod J. 2012 May; 45(5):435-8. [PubMed].

11. Bago I, Plecko V, Gabric DP, Schauperl Z, Baraba A, Anic I. Antimicrobial efficacy of a high-power diode laser,photo-activated disinfection, conventional and sonic activated irrigation during root canal treatment. Int Endod J. 2013 Apr; 46(4):339-47. [PubMed].

12. Alrikaby HA, Balsam SA. Comparison between the Bactericidal Effect of Nd: YAG Laser and Sodium Hypochlorite: An In vitro Study. Int J Med Res Health Sci 2018; 7(11): 4956.

13. Bergmans L, Moisiadis P, Huybrechts B, Van Meerbeek B, Quirynen M, Lambrechts P. Effect of photo-activated disinfection on endodontic pathogens ex vivo. Int Endod J. 2008 Mar;41(3):227-39. [PubMed]

Please cite this article as: Gueorgieva TG, Gergova RT. Comparative study of Antibacterial Activity of photoactivated disinfection with Fotosan and Standard Endodontic Treatment. J of IMAB. 2021 Apr-Jun;27(2):3712-3717.

DOI: https://doi.org/10.5272/jimab.2021272.3712

Received: 07/01/2020; Published online: 26/04/2021

Address for correspondence:

Dr Tzvetelina G. Gueorgieva, PhD,

Department of Conservative Dentistry, Faculty of Dental Medicine, Medical University - Sofia,

1, G. Sofiyski str., Sofia, Bulgaria

E-mail: cvettyg@gmail.com 